\title{
Measurement of bicarbonate output from the intact human oesophagus
}

\author{
C M Brown, C F Snowdon, B Slee, L N Sandle, W D W Rees
}

\begin{abstract}
Injury of the oesophageal mucosa can result from exposure to refluxed gastric acid and pepsin. Competence of the lower oesophageal sphincter and peristaltic activity serve to reduce contract time between luminal acid and oesophageal mucosa, but intraluminal neutralisation of residual acid by bicarbonate may also be important in preventing oesophageal mucosal injury. Whereas swallowed saliva contains bicarbonate, recent experiments have also demonstrated alkali secretion from the mammalian oesophagus. Bicarbonate secretion from the human oesophagus was therefore examined with an intubation technique and perfusion of the oesophagus with a nonabsorbable marker. Saliva, gastric, and oesophageal aspirates were collected and bicarbonate concentrations determined by measurements of $\mathrm{pH}$ and $\mathrm{pCO}_{2}$ or by back titration. In 32 normal subjects ( 17 women, 15 men) median basal oesophageal bicarbonate secretion determined by a $\mathrm{pH} / \mathrm{pCO}_{2}$ method was 416 (range 139-1050) $\mu \mathrm{mol} / \mathrm{hour} / 10 \mathrm{~cm}$. In a subgroup of 15 experiments median oesophageal bicarbonate output was 489 (range 157-1033) $\mu \mathrm{mol} / \mathrm{hour} / \mathbf{1 0} \mathrm{cm} \quad\left(\mathrm{pH} / \mathrm{pCO}_{2}\right.$ method) compared with a median alkali output of 563 (range 135-799) $\mu \mathrm{mol} / \mathrm{hour} / 10 \mathrm{~cm}$ as determined by back titration. The difference was not significant. Salivary contamination of the oesophagus accounted for $25 \%$ of all bicarbonate measured within the oesophagus and refluxed gastric bicarbonate accounted for $\mathbf{2 \cdot 5 \%}$. Bicarbonate secretion from the normal human oesophagus may, in combination with swallowed salivary bicarbonate, play a part in preventing oesophageal mucosal damage due to refluxed gastric acid and pepsin.
\end{abstract}

(Gut 1993; 34: 872-880)

Gastro-oesophageal reflux disease affects over $10 \%$ of the population in the United Kingdom, and symptoms are caused by the presence of excess acid entering the lower oesophagus from the stomach and damaging the surface epithelium. Gastro-oesophageal reflux disease is influenced by the magnitude and duration of acid reflux episodes, ${ }^{1}$ and a number of mechanical factors serve to prevent acid reflux in health. The lower oesophageal sphincter acts as a valve allowing passage of swallowed liquid and food into the stomach, while preventing regurgitation of gastric contents into the oesophagus. Intraabdominal pressure upon the abdominal portion of the oesophagus also minimises reflux after meals and with changes in posture, and the diaphragm may also contribute a little to oesophageal continence. Absence of lower oesophageal sphincter pressure facilitates acid reflux into the oesophagus either by transient relaxations of the sphincter in $82 \%$ of reflux episodes or else by more prolonged absence of sphincter pressure in $13 \%$ of reflux episodes. ${ }^{2}$

Once acid has entered the lower oesophagus peristaltic waves initiated within the body of the oesophagus sweep the bolus away into the stomach, ${ }^{3}$ but may still leave a juxtamucosal acidic environment in the lower oesophagus. Intraluminal neutralisation of acid occurs in part by swallowed saliva and previous studies have shown enhancement of salivary flow in response to dyspeptic symptoms caused by acid entering the lower oesophagus. ${ }^{4}$ Intrinsic bicarbonate secretion from the oesophageal mucosa may also contribute to intraluminal acid neutralisation, and such secretion has been shown in vivo in the opossum oesophagus, which is known to contain submucous glands. ${ }^{5}$ Rabbit oesophagus is devoid of these glands and does not secrete significant quantities of alkali, which suggests the importance of these glands for oesophageal bicarbonate secretion. Similar glands are present throughout the length of the oesophagus in humans ${ }^{6}$ and bicarbonate secretion has previously been found in human stomach and duodenum in vivo. ${ }^{78}$ Experiments were therefore designed to try to show the existence of bicarbonate secretion by the normal human oesophagus. Such alkaline secretion may be important in preventing mucosal injury in some patients with gastrooesophageal reflux disease.

\section{Methods}

The experimental technique involved continuous perfusion of an open segment of oesophagus and the stomach with saline containing nonabsorbable markers. This was by means of a multilumen catheter. Samples were continually aspirated from the oesophagus and stomach, pooled at 15 minute intervals, and analysed for bicarbonate and alkali content. Refluxed gastric alkali was determined by appearance of gastric marker in oesophageal aspirates. Saliva was continually aspirated from the mouth and salivary bicarbonate contamination of the oeso- 
phagus determined by appearance of amylase in oesophageal aspirates. The oesophageal output of bicarbonate or alkali could then be determined.

\section{SUBJECTS}

Experiments were performed on 32 healthy volunteers with no evidence of current or past gastrointestinal disease. Seventeen subjects were women and 15 were men. The median age was 22 (range 18-32) years. Informed written consent was obtained and the experimental techniques were approved by the Salford Health Authority Ethics Committee.

\section{MULTILUMEN CATHETER}

A multilumen polyvinyl chloride tube was constructed from a French size 16 nasogastric tube (internal diameter $3.5 \mathrm{~mm}$, external diameter 5 $\mathrm{mm}$ ) with an infusion port cemented $10 \mathrm{~cm}$ above the aspiration holes of the nasogastric tube by means of tetrahydrofuran (Fisons, Loughborough). The infusion lines were $1 \mathrm{~mm}$ internal diameter and $1.6 \mathrm{~mm}$ external diameter (Portex, Hythe). A size 8 nasogastric tube ( $2 \mathrm{~mm}$ internal diameter, $2.5 \mathrm{~mm}$ external diameter) was cemented on to the assembly with the aspiration holes $10 \mathrm{~cm}$ above the lower infusion port. A second infusion port was cemented on to the assembly $10 \mathrm{~cm}$ above the aspiration holes of the size 8 nasogastric tube, and for in vivo validation studies a third infusion port was cemented on to the assembly at the same point to allow introduction of known amounts of sodium bicarbonate into the upper oesophagus. The intact catheter was $7.5 \mathrm{~mm} \times 5 \mathrm{~mm}$ in cross sectional external diameter. After the first eight experiments, a second size 8 nasogastric tube was cemented on

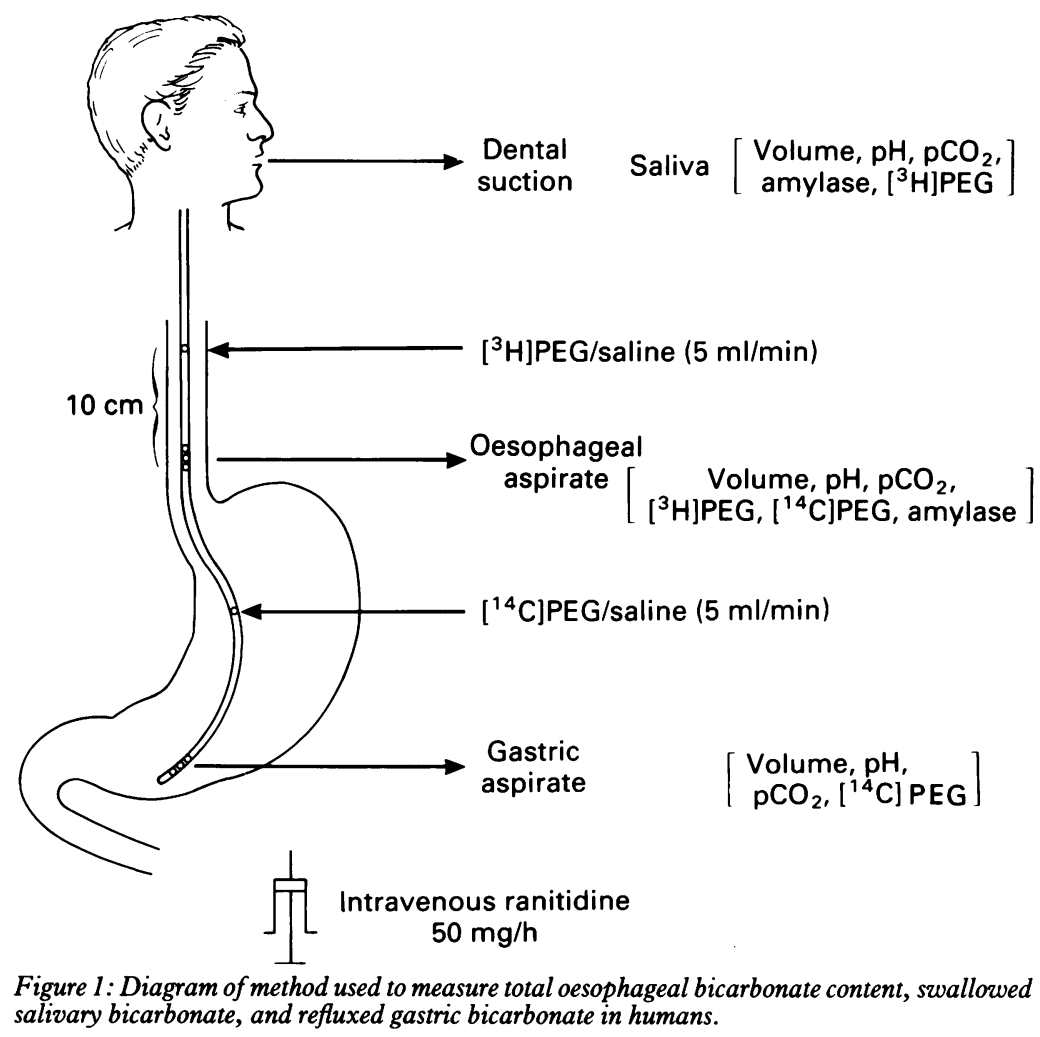

to the assembly with aspiration holes at the same position as the other size 8 nasogastric tube, and both were connected externally by a Y connector. This was to facilitate more efficient aspiration of fluid from the lower oesophagus. Cross sectional diameters of this ovoid tube were $10 \mathrm{~mm} \times 6 \mathrm{~mm}$.

\section{EXPERIMENTAL DESIGN}

Subjects were studied after a nine hour fast and the multilumen tube was passed orally and positioned with the oesophageal aspiration ports (size 8 nasogastric tubes) $35 \mathrm{~cm}$ from the incisors. Positioning was validated fluoroscopically in six subjects, with no adjustment of tube required, and fluoroscopy was therefore not considered essential in subsequent subjects.

Experiments were performed with subjects in a semireclined position and the oesophagus was perfused with $\left[{ }^{3} \mathrm{H}\right]$ polyethylene glycol $\left(\left[{ }^{3} \mathrm{H}\right] \mathrm{PEG} ; \quad 12.5 \mu \mathrm{Ci} /\right.$ litre in $0.9 \%$ sodium chloride adjusted to $\mathrm{pH} 7 \cdot 0$ with $0 \cdot 2 \mathrm{M}$ sodium hydroxide) at a rate of $5 \mathrm{ml} /$ minute. The stomach was similarly perfused with $\left[{ }^{14} \mathrm{C}\right] \mathrm{PEG}(12 \cdot 5 \mu \mathrm{Ci} /$ litre in $0.9 \%$ sodium chloride at $\mathrm{pH} \mathrm{7.0)}$. Oesophageal and gastric contents were continuously aspirated $(-10 \mathrm{~mm} \mathrm{Hg}$ ), collected, and pooled at 15 minute intervals for analysis while fresh $1 \mathrm{ml}$ samples of oesophageal and gastric fluid were collected from the aspiration tubes midway through each 15 minute collection for immediate measurement of $\mathrm{pH}$ and $\mathrm{pCO}_{2}$. Collections were commenced after an initial 45 minute equilibration period during which the oesophagus and stomach were perfused and aspirates discarded. Throughout each experiment subjects were instructed to avoid swallowing saliva, which was collected in 15 minute aliquots by continuous buccal aspiration. Samples $(1 \mathrm{ml})$ were taken for measurement of salivary $\mathrm{pH}$ and $\mathrm{pCO}_{2}$ and the remainder was retained for further analysis.

One hour before intubation subjects were given an oral dose of ranitidine $(300 \mathrm{mg})$, and acid suppression was maintained throughout the experiment by intravenous ranitidine $(50 \mathrm{mg} /$ hour) administered by a cannula (Venflon size $17 \mathrm{G}$ ) sited in a forearm vein (Fig 1).

\section{ANALYSIS AND CALCULATIONS}

\section{Bicarbonate concentrations}

The $\mathrm{pH}$ and $\mathrm{pCO}_{2}$ of fresh aspirates were immediately measured with a Corning $170 \mathrm{pH} /$ blood gas analyser (Ciba Corning, Essex). When $\mathrm{pH}$ was outside the calibrated range $(6.838$ to $7 \cdot 382$ ) it was recorded manually by a glass electrode attached to a standard pH meter (PHM 82 , Radiometer, Copenhagen) and calibrated by

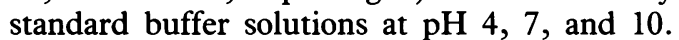
With these values the oesophageal and gastric $\mathrm{HCO}_{3}{ }^{-}$concentrations ( $\mathrm{mmol} /$ litre) were calculated from the equations:

\footnotetext{
$\mathrm{HCO}_{3}{ }^{-}$, as $\mathrm{CO}_{2}=\mathrm{pCO}_{2} \times$ solubility constant

Free $\mathrm{HCO}_{3}{ }^{-}$from $\mathrm{pH}=\mathrm{pka}+\log \frac{\text { free bicarbonate }}{\mathrm{pCO}_{2} \times \text { solubility constan }}$
} 


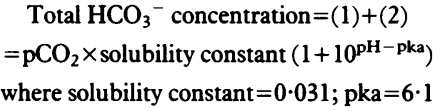

Oesophageal volume and volume of gastric refluxate The oesophageal volume represents that volume available within which bicarbonate of oesophageal origin can be distributed. It includes volume of oesophageal perfusate $(75 \mathrm{ml} / 15$ minutes), volume of oesophageal secretion, volume of swallowed saliva, and volume of gastric refluxate.

In a steady state perfusion system:

$$
\mathrm{C}_{1} \times \mathrm{V}_{1}=\mathrm{C}_{2} \times \mathrm{V}_{2}
$$

where $\mathrm{C}_{1}=$ concentration of non-absorbable marker $\left[{ }^{3} \mathrm{H}\right] \mathrm{PEG}$ in infusate; $V_{1}=$ volume of infusate $(75 \mathrm{~m} / 15$ minutes); $\mathrm{C}_{2}=$ concentration of non-absorbable marker $\left[{ }^{3} \mathrm{H}\right] \mathrm{PEG}$ in oesophageal aspirates.

Hence the oesophageal volume $V_{2}$ can be determined:

Oesophageal volume $=$ volume infused $(75 \mathrm{ml} / 15 \mathrm{~min}) \times$ $\left[\left[^{3} \mathrm{H}\right]\right.$ PEG] infusate

$\overline{\left[{ }^{3} \mathrm{H}\right] \text { PEG] oesophageal aspirate }}$

The volume of gastric refluxate can be determined by appearance of the gastric nonabsorbable marker, $\left[{ }^{14} \mathrm{C}\right] \mathrm{PEG}$, in oesophageal spirates:

Volume of gastric refluxate $=$ Oesophageal volume $\times$

$$
\frac{\left[\left[{ }^{14} \mathrm{C}\right] \mathrm{PEG}\right] \text { oesophageal aspirate }}{\left[\left[{ }^{14} \mathrm{C}\right] \mathrm{PEG}\right] \text { gastric aspirate }}
$$

The $\left[{ }^{3} \mathrm{H}\right]$ and $\left[{ }^{14} \mathrm{C}\right] P E G$ concentrations in oesophageal and gastric samples were determined by dual isotope counting with an LKB $\beta$ scintillation counter (LKB Wallac 81000, Sweden). Determinations of oesophageal volume and volume of gastric refluxate were by adaptations of previously described methods. ${ }^{79}$

The oesophageal $\mathrm{HCO}_{3}{ }^{-}$content and $\mathrm{HCO}_{3}{ }^{-}$ refluxed from the stomach could then be calculated:

$$
\begin{gathered}
\text { Oesophageal } \mathrm{HCO}_{3}{ }^{-} \text {content }(\mu \mathrm{mol} / 15 \mathrm{~min})= \\
\text { oesophageal volume }(\mathrm{ml} / 15 \mathrm{~min}) \times \\
\text { oesophageal } \mathrm{HCO}_{3}{ }^{-} \text {concentration }(\mathrm{mmol} / \mathrm{l}) \\
\text { Refluxed gastric } \mathrm{HCO}_{3}{ }^{-}= \\
\text {volume refluxed } \times \text { gastric } \mathrm{HCO}_{3}{ }^{-} \text {concentration }
\end{gathered}
$$

\section{Salivary $\mathrm{HCO}_{3}{ }^{-}$contamination}

The $\mathrm{pH}$ and $\mathrm{pCO}_{2}$ of saliva were measured at 15 minute intervals to determine $\mathrm{HCO}_{3}{ }^{-}$concentration. Amylase concentrations were measured in paired salivary and oesophageal fluid samples by an automated enzymatic method. ${ }^{10} 11$ Contaminaton of oesophageal fluid by swallowed salivary $\mathrm{HCO}_{3}{ }^{-}$was determined from the equations:

$$
\begin{aligned}
& \text { Contaminating salivary } \mathrm{HCO}_{3}{ }^{-}=\text {volume of contaminating saliva } \\
& \times \text { salivary } \mathrm{HCO}_{3}{ }^{-} \text {concentration } \\
& \text { Salivary } \mathrm{HCO}_{3}{ }^{-} \text {concentration }=\mathrm{pCO}_{2} \times 0.031\left(1+10^{\mathrm{pH}-\mathrm{pka}}\right) \\
& \text { Volume of contaminating saliva }=\text { oesophageal volume } \times \\
& \text { [amylase] oesophageal aspirate } \\
& \text { [amylase] saliva }
\end{aligned}
$$

Hence net oesophageal bicarbonate secretion can be determined:

$=$ total bicarbonate within oesophagus $-\left(\right.$ refluxed gastric $\mathrm{HCO}_{3}$ + swallowed salivary $\mathrm{HCO}_{3}^{-}$)
Also, total salivary bicarbonate secretion could be calculated:

$=$ (volume of swallowed saliva + volume of buccally aspirated saliva $)$ $\times\left[\mathrm{HCO}_{3}^{-}\right]$saliva

\section{VALIDATION STUDIES}

\section{In vivo infusion of sodium bicarbonate}

Experiments were performed on seven subjects to determine the accuracy of the method for measuring oesophageal bicarbonate content. After a 45 minute equilibration period, salivary oesophageal and gastric aspirates were collected and pooled at 15 minute intervals for one hour, and $\mathrm{pH}$ and $\mathrm{pCO}_{2}$ were measured in fresh samples to determine basal oesophageal bicarbonate secretion as already described. During the next 15 minute period a $5 \mathrm{ml}$ bolus containing a known amount of sodium bicarbonate $(100,200$, 500 , or $1000 \mu \mathrm{mol}$ ) was infused slowly and the total amount of bicarbonate determined by dilution of $\left[{ }^{3} \mathrm{H}\right] \mathrm{PEG}$ and $\mathrm{pH}$ and $\mathrm{pCO}_{2}$ of oesophageal aspirates. In most subjects a second bolus containing a different quantity of bicarbonate to the first was infused 30 minutes after the first bolus. The 15 minute basal rate of oesophageal bicarbonate secretion was subtracted from the calculated bicarbonate outputs during periods when exogenous bicarbonate was infused, to calculate the quantity of infused bicarbonate.

\section{Measurements of amylase in oesophageal fluid}

Because saliva contains high concentrations of bicarbonate, even small volumes of swallowed saliva may significantly contaminate the oesophageal segment. Confidence in the amylase measurements in oesophageal fluid as a marker of salivary contamination is therefore essential. The major potential confounder in this analysis is $\mathrm{pH}$, because $\mathrm{pH}$ values of oesophageal fluid are about $1.0 \log$ point lower than $\mathrm{pH}$ values of saliva. Studies were therefore required to exclude a major effect of $\mathrm{pH}$ on measurements of amylase.

Saliva and oesophageal fluid were taken from two subjects and pooled. $\mathrm{pH}$ of the saliva pool was $8 \cdot 20$ whereas $\mathrm{pH}$ of the oesophageal pool was $7 \cdot 20$. Each pool was divided into two subgroups and one saliva subpool was titrated down to $\mathrm{pH}$ $7 \cdot 20$ with $0 \cdot 1 \mathrm{~N} \mathrm{HCl}$ and one oesophageal fluid subpool was titrated up to $\mathrm{pH} 8 \cdot 20$ with $0 \cdot 2 \mathrm{~N}$ $\mathrm{NaOH}$. In each of the four subpools, 20 or 21 estimations of amylase activity were performed. Oesophageal fluid was undiluted but salivary samples were diluted to 1 in 30 to bring amylase values into the known linear range for the assay. Amylase concentrations in saliva and oesophageal fluid were compared at both $\mathrm{pH} 7 \cdot 20$ and $8 \cdot 20$.

Bicarbonate and alkali output: comparison of the $\mathrm{pH} / \mathrm{pCO} \mathrm{C}_{2}$ method and the back-titration method

In 15 subjects oesophageal bicarbonate secretion was determined by the $\mathrm{pH} / \mathrm{pCO}_{2}$ technique described earlier. Also, alkali concentrations were determined in salivary, oesophageal, and 


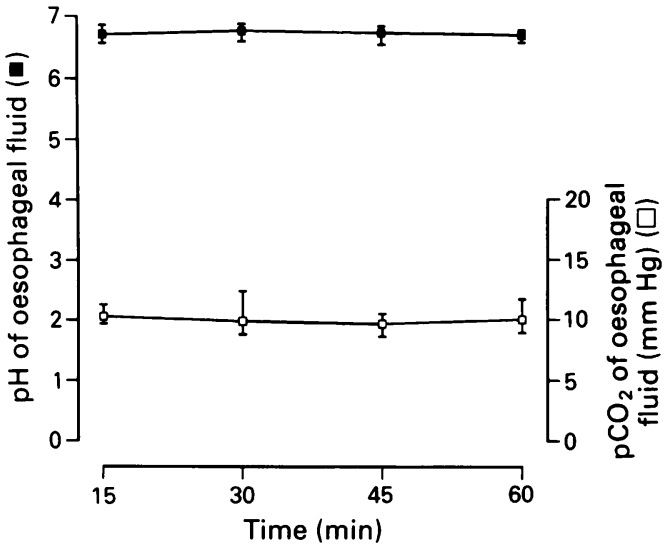

Figure 2: Basal oesophageal fluid $p \mathrm{H}$ and $p \mathrm{CO}_{2}$ in 32 subjects over 60 minutes. Median values and $95 \%$ confidence intervals are given.

gastric samples by a previously described sensitive back titration technique. ${ }^{9}$ Briefly, a known excess of $\mathrm{H}^{+}$ions $\left(250 \mu \mathrm{l}\right.$ of $0 \cdot 1 \mathrm{M} \mathrm{H}_{2} \mathrm{SO}_{4}=50$ $\mu \mathrm{Eq} \mathrm{H}^{+}$) was added to $2 \mathrm{ml}$ of sample and $5 \mathrm{ml}$ of deionised $\mathrm{H}_{2} \mathrm{O}$. This was gassed with $\mathrm{CO}_{2}$ free nitrogen (washed through saturated barium hydroxide solution) for five minutes to remove dissolved $\mathrm{CO}_{2}$ from the sample, which was then titrated up to the reaction endpoint at $\mathrm{pH} 8.4$ (pH meter PHM 82 linked to an autoburette ABU 80 and controlled by an autotitrator TTT 80 all units Radiometer, Copenhagen) with 15 $\mathrm{mM} \mathrm{NaOH}$. The alkali content of each sample was determined from the volume of titrant required to reach the reaction endpoint.

Net oesophageal alkali output was calculated from the previously described volume measurements.

\section{In vitro alkali studies}

To determine the accuracy of back titration in determining alkali concentrations, triplicate measurements of alkali concentrations were performed on standard bicarbonate solutions $(1,2$, $2 \cdot 5,5,10,15,20$, and $25 \mathrm{mM}$ sodium bicarbonate), deionised water, and standard oesophageal perfusate containing $\left[{ }^{3} \mathrm{H}\right] \mathrm{PEG}$ and titrated to $\mathrm{pH} 7 \cdot 0$ with $0 \cdot 2 \mathrm{M} \mathrm{NaOH}$.

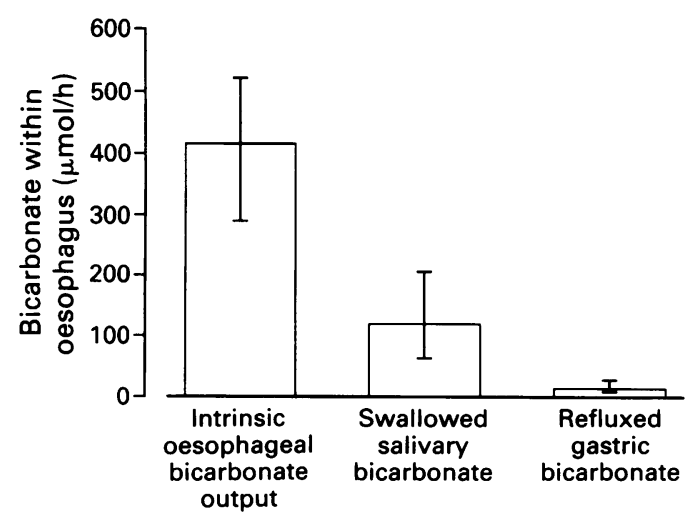

Figure 3: Basal bicarbonate secretion from a $10 \mathrm{~cm}$ segment of oesophagus, and salivary and gastric bicarbonate contamination of the oesophagus in 32 subjects. Median values and $95 \%$ confidence intervals are given.
ACID PERFUSION STUDIES

After a 45 minute equilibration period and a further 60 minutes during which time basal salivary bicarbonate secretion was determined, the oesophageal perfusion solution was changed from saline (containing $12 \cdot 5 \mu \mathrm{Ci} /$ litre $\left[{ }^{3} \mathrm{H}\right] \mathrm{PEG}$ ) to $0.1 \mathrm{~N}$ hydrochloric acid (containing $12.5 \mu \mathrm{Ci}$ / litre $\left.\left[{ }^{3} \mathrm{H}\right] \mathrm{PEG}\right)$. Acid was perfused at a rate of $5 \mathrm{ml} / \mathrm{minute}$ for five minutes in eight subjects and for 30 minutes in 12 subjects. During this time it was not possible to determine oesophageal bicarbonate outputs by the $\mathrm{pH} / \mathrm{pCO}_{2}$ method as the $\mathrm{pH}$ was below $6 \cdot 1$. The salivary secretory response to oesophageal acidification was, however, examined.

\section{STATISTICAL ANALYSIS OF DATA}

The data were analysed on the computer with Minitab 7.1. As most were not normally distributed, results are expressed as median values with $95 \%$ confidence intervals ( $95 \%$ CIs). Significance levels for comparative data were determined by the Wilcoxon signed rank test. Independent data populations such as the percentage marker recovery from single and twin lumen oesophageal aspiration assemblies were examined for significant differences with the Mann-Whitney test.

\section{Results}

\section{OESOPHAGEAL MARKER RECOVERY}

Percentage recovery of the oesophageal marker was determined from the volume of the 15 minute oesophageal aspirates and their $\left[{ }^{3} \mathrm{H}\right] \mathrm{PEG}$ concentrations. In the first eight subjects median recovery of the oesophageal marker from the single oesophageal lumen aspiration assembly was $26 \cdot 4 \%(95 \%$ CI $15 \cdot 5-37 \cdot 0)$. Efficiency of recovery increased in the subsequent 24 subjects with the twin lumen oesophageal aspiration assembly, with a median marker recovery of $48 \cdot 2 \%(95 \%$ CI $42 \cdot 7-56 \cdot 9)$.

\section{BASAL BICARBONATE SECRETION IN HUMAN OESOPHAGUS}

After a 45 minute equilibration period, bicarbonate content of the oesophagus and contamination by swallowed salivary bicarbonate and refluxed gastric bicarbonate were measured over 60 minutes. Intragastric $\mathrm{pH}$ was maintained between pH 6 and 7 with ranitidine. Oesophageal fluid $\mathrm{pH}$ was consistent with median $\mathrm{pH}$ values of 6.71 to 6.66 over 60 minutes. More variability in corresponding $\mathrm{pCO}_{2}$ values were found with medians of 10.3 to $10.0 \mathrm{~mm} \mathrm{Hg}$ over 60 minutes (Fig 2). Net oesophageal bicarbonate secretion in 32 subjects, after deductions for contaminating salivary and gastric bicarbonate, ranged from $139 \cdot 2 \mu \mathrm{mol} /$ hour $/ 10 \mathrm{~cm}$ to 1050 $\mu \mathrm{mol} / \mathrm{hour} / 10 \mathrm{~cm}$ with a median of $416.3 \mu \mathrm{mol} /$ hour $/ 10 \mathrm{~cm}(95 \%$ CI $290 \cdot 4-521 \cdot 8)$ (Fig 3).

SALIVARY CONTAMINATION OF OESOPHAGEAL CONTENTS

All oesophageal samples in all subjects contained 
TABLE I Individual data in 32 subjects indicating number of analysable periods, percentage oesophageal marker recovery, net oesophageal bicarbonate output, and contamination by both swallowed saliva and refluxed gastric fluid

\begin{tabular}{|c|c|c|c|c|c|c|}
\hline \multicolumn{3}{|c|}{ Subject } & \multirow[b]{2}{*}{$\begin{array}{l}\% \text { Marker } \\
\text { recovery }\end{array}$} & \multirow{2}{*}{$\begin{array}{l}\text { Net oesophageal } \\
\mathrm{HCO}_{3}^{-} \text {secretion } \\
(\mu \mathrm{mol} / \mathrm{h} / 10 \mathrm{~cm})\end{array}$} & \multirow{2}{*}{$\begin{array}{l}\text { Salivary } \mathrm{HCO}_{3}{ }^{-} \\
\text {contamination } \\
(\mu \mathrm{mol} / \mathrm{h})\end{array}$} & \multirow{2}{*}{$\begin{array}{l}\text { Gastric } \\
\mathrm{HCO}_{3}^{-} \\
\text {contamination } \\
(\mu \mathrm{mol} / \mathrm{h})\end{array}$} \\
\hline No & Sex & $\begin{array}{l}\text { Periods of } \\
\text { analysis }\end{array}$ & & & & \\
\hline 1 & M & 4 & $36 \cdot 6$ & 460.9 & $216 \cdot 2$ & $3 \cdot 0$ \\
\hline 2 & $M$ & 4 & $24 \cdot 4$ & $377 \cdot 1$ & $71 \cdot 4$ & $16 \cdot 6$ \\
\hline 3 & $\mathrm{~F}$ & 4 & $24 \cdot 7$ & 779.5 & $211 \cdot 1$ & $42 \cdot 0$ \\
\hline 4 & $\mathrm{~F}$ & 4 & $14 \cdot 3$ & 1050.0 & $528 \cdot 7$ & $255 \cdot 5$ \\
\hline 5 & $M$ & 4 & $28 \cdot 2$ & $244 \cdot 0$ & 394.9 & 6.0 \\
\hline 6 & $M$ & 4 & $15 \cdot 6$ & 198.0 & $7 \cdot 1$ & 3.4 \\
\hline 7 & M & 4 & 28.9 & $238 \cdot 5$ & $63 \cdot 5$ & $28 \cdot 0$ \\
\hline 8 & $F$ & 4 & $43 \cdot 5$ & $139 \cdot 2$ & 11.9 & 38.9 \\
\hline 9 & $\mathbf{F}$ & 3 & $43 \cdot 2$ & 256.0 & $119 \cdot 4$ & $14 \cdot 3$ \\
\hline 10 & $M$ & 3 & 86.0 & $431 \cdot 3$ & 6.4 & $66 \cdot 7$ \\
\hline 11 & $\mathrm{~F}$ & 4 & $21 \cdot 6$ & $450 \cdot 0$ & $69 \cdot 8$ & $72 \cdot 2$ \\
\hline 12 & $\mathrm{~F}$ & 3 & 53.5 & $561 \cdot 2$ & 3.5 & 199.6 \\
\hline 13 & $\mathrm{~F}$ & 3 & 59.5 & $603 \cdot 7$ & 106.0 & $14 \cdot 3$ \\
\hline 14 & M & 4 & $48 \cdot 4$ & $222 \cdot 8$ & $15 \cdot 1$ & $308 \cdot 3$ \\
\hline 15 & $\mathbf{F}$ & 4 & $55 \cdot 0$ & 371.8 & $46 \cdot 4$ & 11.6 \\
\hline 16 & $\mathrm{~F}$ & 4 & $45 \cdot 2$ & 290.5 & $2 \cdot 9$ & $141 \cdot 0$ \\
\hline 17 & $M$ & 4 & 58.6 & $305 \cdot 0$ & 15.9 & 0 \\
\hline 18 & $\mathrm{~F}$ & 4 & $33 \cdot 0$ & $251 \cdot 2$ & $117 \cdot 8$ & $11 \cdot 3$ \\
\hline 19 & $\mathrm{~F}$ & 4 & $40 \cdot 4$ & $521 \cdot 7$ & 11.6 & 12.9 \\
\hline 20 & M & 4 & $73 \cdot 0$ & $393 \cdot 2$ & $201 \cdot 7$ & $19 \cdot 7$ \\
\hline 21 & M & 4 & $81 \cdot 2$ & $157 \cdot 0$ & $3 \cdot 2$ & $3 \cdot 7$ \\
\hline 22 & M & 4 & $43 \cdot 1$ & $417 \cdot 9$ & 250.9 & $54 \cdot 3$ \\
\hline 23 & M & 4 & 59.9 & $567 \cdot 4$ & $150 \cdot 5$ & 10.8 \\
\hline 24 & M & 3 & $47 \cdot 2$ & $414 \cdot 7$ & $206 \cdot 2$ & $9 \cdot 1$ \\
\hline 25 & M & 3 & $61 \cdot 7$ & $243 \cdot 1$ & $168 \cdot 3$ & $21 \cdot 4$ \\
\hline 26 & $\mathrm{~F}$ & 4 & $29 \cdot 6$ & $489 \cdot 5$ & $350 \cdot 0$ & $1 \cdot 2$ \\
\hline 27 & $\mathrm{~F}$ & 3 & $26 \cdot 7$ & $838 \cdot 6$ & $77 \cdot 9$ & $4 \cdot 4$ \\
\hline 28 & $\mathrm{~F}$ & 4 & $56 \cdot 5$ & $206 \cdot 3$ & $419 \cdot 0$ & 1.4 \\
\hline 29 & $\mathrm{~F}$ & 4 & 40.6 & $1033 \cdot 6$ & 165.9 & $3 \cdot 6$ \\
\hline 30 & M & 4 & $53 \cdot 1$ & 640.5 & $311 \cdot 5$ & $12 \cdot 1$ \\
\hline 31 & $\mathrm{~F}$ & 4 & 35.5 & $828 \cdot 1$ & 288.6 & 66.1 \\
\hline 32 & $\mathrm{~F}$ & 6 & 48.0 & $665 \cdot 6$ & 276.0 & 2.9 \\
\hline
\end{tabular}

varying amylase concentrations indicative of swallowed saliva, and the amount of bicarbonate in the oesophagus derived from saliva was calculated. Continuous buccal aspiration was efficient, collecting a median $97 \%$ of saliva, although $3 \%$ of saliva was swallowed $(95 \%$ CI $1 \cdot 0-4 \cdot 7)$.

A median of $118.6 \mu \mathrm{mol} / \mathrm{hour}$ of salivary bicarbonate was swallowed $(95 \%$ CI $63 \cdot 5-206 \cdot 2)$, accounting for about $25 \%$ of all bicarbonate within the oesophageal segment (Fig 3).

GASTRIC REFLUX OF BICARBONATE INTO THE OESOPHAGUS

Reflux of gastric biocarbonate into the oesoph-

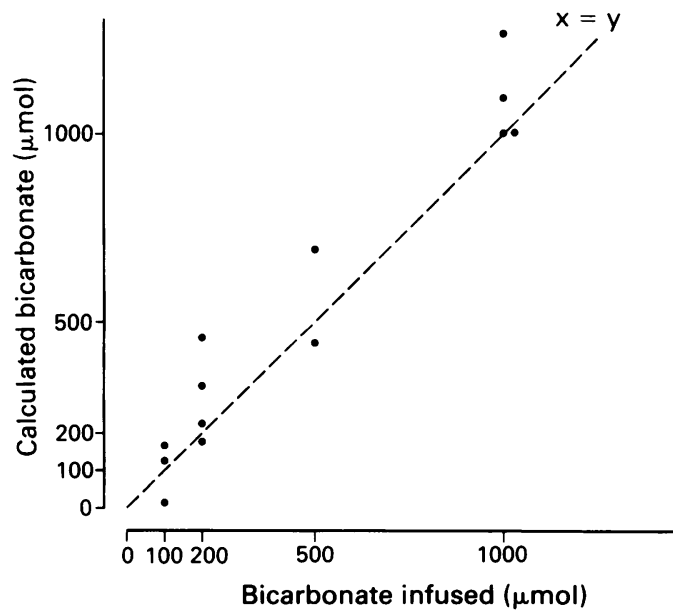

Figure 4: Relation between infused and calculated exogenous bicarbonate in seven subjects (correlation coefficient $r=0.965$, $p=0.0001$, average difference $=+69 \mu \mathrm{mol})$.

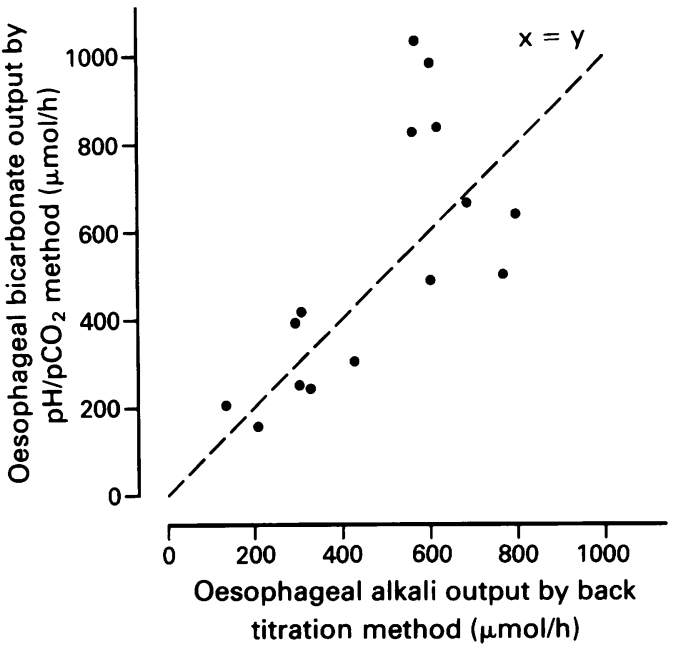

Figure 5: Comparison of bicarbonate output from a $10 \mathrm{~cm}$ segment of oesophagus determined by the $\mathrm{pH} / \mathrm{pCO} \mathrm{C}_{2}$ method, with oesophageal alkali output determined by the back titration method in 15 experiments $(r=0 \cdot 69, p<0 \cdot 02$, no significant bias $p=0 \cdot 38$ ).

agus was determined from the appearance of gastric marker $\left[{ }^{14} \mathrm{C}\right] \mathrm{PEG}$ in oesophageal aspirates and bicarbonate concentration of gastric fluid. A median of $13.6 \mu \mathrm{mol} /$ hour of gastric bicarbonate refluxed into the oesophageal segment (95\% CI 9.1-28.0) accounted for about $2.5 \%$ of total bicarbonate within the oesophagus (Fig 3).

Table I presents data for individual subjects.

\section{VALIDATION STUDIES}

In vivo infusion of sodium bicarbonate

The results show an excellent correlation between the quantity of bicarbonate infused into the oesophagus and that measured and calculated from the aspirates (correlation coefficient $r=0.965, p=0.0001$, Fig 4). These results reflect accuracy, not only of bicarbonate concentration determination, but also of volume measurements including contaminating saliva and gastric fluid.

Measurement of amylase in oesophageal fluid

Because saliva contains relatively high concentrations of alkali, accounting for about $25 \%$ of bicarbonate within the oesophagus, it is important that amylase concentrations measured in oesophageal fluid accurately reflect salivary contamination.

Median amylase concentration in saliva at $\mathrm{pH}$ $7 \cdot 20$ was $4229 \mathrm{U} / 1(\mathrm{n}=20)$, coeficient of variation $2 \%$ ), and at $\mathrm{pH} 8 \cdot 20$ median amylase concentration was $4321 U / 1(n=20$, coeficient of variation $=2 \%$ ). Thus reduction in $\mathrm{pH}$ of saliva from $\mathrm{pH}$ $8 \cdot 2$ to $7 \cdot 2$ accounted for a $2 \cdot 2 \%$ reduction in amylase detection $(\mathrm{p}=0 \cdot 004)$. Median amylase activity in oesophageal fluid at $\mathrm{pH} 7 \cdot 20$ was 2825 $\mathrm{U} / 1 \quad(\mathrm{n}=21$, coefficient of variation $=2 \cdot 5 \%)$ whereas at $\mathrm{pH} 8.20$ median amylase activity was $2859 \mathrm{U} / \mathrm{l}(\mathrm{n}=21$, coefficient of variation= $2.7 \%$ ); the difference was not significant $(\mathrm{p}=0.55)$. 
TABLE II Oesophageal bicarbonate and alkali output, swallowed saliva, and refluxed gastric contamination in 13 subjects (15 experiments): individual data comparing the two methods

\begin{tabular}{|c|c|c|c|c|c|c|c|}
\hline & & \multicolumn{3}{|l|}{$\mathrm{pH} p \mathrm{CO}_{2}$ method } & \multicolumn{3}{|l|}{ Back titration } \\
\hline \multicolumn{2}{|c|}{ Subject } & \multirow{2}{*}{$\begin{array}{l}\text { Oesophageal } \\
\mathrm{HCO}_{3}^{-} \text {output } \\
(\mu \mathrm{mol} / \mathrm{h} / 10 \mathrm{~cm})\end{array}$} & \multirow{2}{*}{$\begin{array}{l}\text { Salivary } \\
\text { contamination } \\
(\mu \text { mol/h })\end{array}$} & \multirow{2}{*}{$\begin{array}{l}\text { Gastric } \\
\text { contamination } \\
(\mu \mathrm{mol} / \mathrm{h})\end{array}$} & \multirow{2}{*}{$\begin{array}{l}\text { Oesophageal alkali } \\
\text { output } \\
(\mu \mathrm{mol} / \mathrm{h} / 10 \mathrm{~cm})\end{array}$} & \multirow{2}{*}{$\begin{array}{l}\text { Salivary } \\
\text { contamination } \\
(\mu \text { mol/h })\end{array}$} & \multirow{2}{*}{$\begin{array}{l}\text { Gastric } \\
\text { contamination } \\
(\mu \mathrm{mol} / \mathrm{h})\end{array}$} \\
\hline No & Sex & & & & & & \\
\hline 17 & M & 305.0 & 15.9 & 0 & $429 \cdot 0$ & $20 \cdot 0$ & 0 \\
\hline 18 & $\mathrm{~F}$ & $251 \cdot 2$ & $117 \cdot 8$ & $11 \cdot 3$ & $304 \cdot 1$ & $122 \cdot 2$ & $11 \cdot 3$ \\
\hline 20 & M & $393 \cdot 2$ & $201 \cdot 7$ & $19 \cdot 7$ & $295 \cdot 2$ & $145 \cdot 2$ & $8 \cdot 7$ \\
\hline 21 & M & 157.0 & $3 \cdot 2$ & $3 \cdot 7$ & $209 \cdot 5$ & $2 \cdot 0$ & $2 \cdot 8$ \\
\hline 22 & M & 417.9 & 250.9 & $54 \cdot 3$ & $309 \cdot 1$ & $97 \cdot 6$ & $15 \cdot 0$ \\
\hline 25 & M & $243 \cdot 1$ & $168 \cdot 3$ & $21 \cdot 4$ & $329 \cdot 1$ & 313.5 & $2 \cdot 6$ \\
\hline 26 & $\mathrm{~F}$ & $489 \cdot 5$ & $350 \cdot 0$ & $1 \cdot 2$ & 603.9 & $66 \cdot 5$ & 1.4 \\
\hline \multirow[t]{2}{*}{27} & $F(a)$ & $838 \cdot 6$ & $77 \cdot 9$ & $4 \cdot 4$ & $619 \cdot 1$ & $71 \cdot 9$ & $2 \cdot 8$ \\
\hline & (b) & 983.8 & $125 \cdot 1$ & $5 \cdot 6$ & $603 \cdot 3$ & $28 \cdot 1$ & $3 \cdot 4$ \\
\hline 28 & $\mathrm{~F}$ & $206 \cdot 3$ & $419 \cdot 0$ & $1 \cdot 4$ & $135 \cdot 3$ & $110.5^{\circ}$ & $1 \cdot 0$ \\
\hline 29 & $F$ & 1033.6 & 165.9 & $3 \cdot 6$ & $569 \cdot 5$ & $47 \cdot 7$ & $2 \cdot 6$ \\
\hline 30 & $M$ & 640.5 & $311 \cdot 5$ & $12 \cdot 1$ & $799 \cdot 2$ & $146 \cdot 8$ & $4 \cdot 6$ \\
\hline 31 & $\mathrm{~F}$ & $828 \cdot 1$ & 288.6 & $66 \cdot 1$ & 563.4 & $114 \cdot 2$ & $20 \cdot 8$ \\
\hline \multirow[t]{2}{*}{32} & $F(a)$ & $665 \cdot 6$ & $276 \cdot 0$ & $2 \cdot 9$ & $687 \cdot 9$ & $113 \cdot 8$ & 1.6 \\
\hline & (b) & $502 \cdot 0$ & $14 \cdot 4$ & $1 \cdot 3$ & $770 \cdot 0$ & $10 \cdot 0$ & $2 \cdot 6$ \\
\hline
\end{tabular}

In vivo human oesophageal bicarbonate and alkali outputs: comparison of $\mathrm{pH} / \mathrm{pCO} \mathrm{O}_{2}$ and back titration methods

In 15 experiments median oesophageal bicarbonate concentration was $2.06 \mathrm{mmol} / 1(95 \% \mathrm{CI}$ 1.57-2.64) derived from $\mathrm{pH}$ and $\mathrm{pCO}_{2}$ whereas median oesophageal alkali concentration was $1.65 \mathrm{mmol} / 1$ (95\% CI 1.32-2.08), determined by back titration. This difference achieved significance $(p=0.04)$

Although the $\mathrm{pH} / \mathrm{pCO}_{2}$ method overcalculates the alkali content of oesophageal fluid by about $25 \%$, there is a greater error in salivary alkali determination by the $\mathrm{pH} / \mathrm{pCO}_{2}$ method probably attributable to the higher $\mathrm{pH}$. Median bicarbonate concentration in saliva determined by the former method was $28 \cdot 1 \mathrm{mmol} / 1$ (95\% CI 19.79$38.74)$ compared with $14.74 \mathrm{mmol} / \mathrm{l}$ alkali in saliva determined by back titration $(95 \% \mathrm{CI}$, $12 \cdot 95-16 \cdot 69)$ - that is, a $90 \%$ overestimation ( $p=$ $0.003)$.

Overall when bicarbonate or alkali outputs from the oesophagus were determined after deductions for contaminating saliva and gastric fluid, there was a good correlation between the two methods. Median oesophageal bicarbonate secretion was $489.5 \mu \mathrm{mol} / \mathrm{hour} / 10 \mathrm{~cm}(95 \% \mathrm{CI}$ 271-767), compared with median alkali output of $563.4 \mu \mathrm{mol} / \mathrm{hour} / 10 \mathrm{~cm}(95 \%$ CI $306-613)$. There was a significant correlation between the two methods $(r=0.69 ; \mathrm{p}<0.02)$, with no significant bias $(\mathrm{p}=0.38)$ (Fig 5)

Due to the differences in salivary bicarbonate

TABLE III Data illustrating the intrasubject variation in oesophageal bicarbonate secretion, swallowed salivary bicarbonate, and refluxed gastric bicarbonate in six subjects when examined on two separate occasions by the $\mathrm{pH} / \mathrm{pCO} \mathrm{O}_{2}$ method, and in two subjects by back titration

\begin{tabular}{|c|c|c|c|c|c|c|}
\hline \multirow{2}{*}{$\begin{array}{l}\text { Subject } \\
\text { No }\end{array}$} & \multicolumn{2}{|c|}{$\begin{array}{l}\text { Oesophageal bicarbonate } \\
\text { secretion } \\
(\mu \mathrm{mol} / \mathrm{h} / 10 \mathrm{~cm})\end{array}$} & \multicolumn{2}{|c|}{$\begin{array}{l}\text { Salivary contamination } \\
(\mu \mathrm{mol} / \mathrm{h})\end{array}$} & \multicolumn{2}{|c|}{$\begin{array}{l}\text { Refluxed gastric } \\
\text { contamination } \\
(\mu \text { mol/h) }\end{array}$} \\
\hline & Study 1 & Study 2 & Study 1 & Study 2 & Study 1 & Study 2 \\
\hline \multicolumn{7}{|c|}{$\mathrm{pH} / \mathrm{p} C \mathrm{O}_{2}$ method } \\
\hline $\begin{array}{r}7 \\
8 \\
9 \\
13 \\
27 \\
32\end{array}$ & $\begin{array}{l}238 \\
139 \\
256 \\
604 \\
839 \\
666\end{array}$ & $\begin{array}{l}158 \\
301 \\
255 \\
301 \\
984 \\
502\end{array}$ & $\begin{array}{r}63 \\
12 \\
119 \\
106 \\
78 \\
276\end{array}$ & $\begin{array}{r}44 \\
5 \\
17 \\
112 \\
125 \\
14\end{array}$ & $\begin{array}{r}28 \\
39 \\
14 \\
14 \\
4 \\
3\end{array}$ & $\begin{array}{c}4 \\
10 \\
13 \\
53 \\
6 \\
1 \cdot 3\end{array}$ \\
\hline \multicolumn{7}{|c|}{ Back titration } \\
\hline $\begin{array}{l}27 \\
32\end{array}$ & $\begin{array}{l}619 \\
688\end{array}$ & $\begin{array}{l}603 \\
770\end{array}$ & $\begin{array}{r}72 \\
114\end{array}$ & $\begin{array}{l}28 \\
10\end{array}$ & $\begin{array}{l}3 \\
2\end{array}$ & $\begin{array}{l}3 \\
3\end{array}$ \\
\hline
\end{tabular}

and salivary alkali concentrations determined by the $\mathrm{pH} / \mathrm{pCO}_{2}$ or back titration method, there are pronounced differences in total salivary outputs in 15 experiments (13 subjects). Median basal salivary bicarbonate output ( $\mathrm{pH} / \mathrm{pCO}_{2}$ method) was $4473 \mu \mathrm{mol} /$ hour (95\% CI 2595-7999), whereas median basal salivary alkali output was $2777 \mu \mathrm{mol} /$ hour (95\% CI, 2098-3540). The difference is significant $(\mathrm{p}=0 \cdot 003)$.

Table II shows individual data comparing the two methods of bicarbonate and alkali determination.

\section{In vitro alkali studies}

There is an excellent correlation between actual and measured concentration of alkali in standard bicarbonate solutions $(0,1,2,2 \cdot 5,5,10,15,20$, and $25 \mathrm{mM}$ of $\mathrm{NaHCO}_{3}$ ) (Fig 6). This validates the accuracy of the back titration technique in determining the alkali content of solutions $(r=$ $1 \cdot 0, p=0 \cdot 0001)$. The average percentage difference between actual and measured alkali content was $0 \cdot 2 \%$. Oesophageal perfusing solutions ( $0.9 \%$ sodium chloride containing $12.5 \mu \mathrm{Ci} / 1$ of $\left[{ }^{3} \mathrm{H}\right] \mathrm{PEG}$, were titrated to $\mathrm{pH} 7 \cdot 0$ with $0.2 \mathrm{M}$ $\mathrm{NaOH}$ and were found to contain no titratable alkali.

INTRASUBJECT VARIATION

Six subjects were examined on two separate occasions and mean basal oesophageal bicarbonate outputs, and salivary, and gastric bicarbonate contamination of the oesophagus were quantified by the $\mathrm{pH} / \mathrm{pCO}_{2}$ method (Table III). Oesophageal alkali outputs were also determined in two subjects on separate occasions by back titration (Table III). There are reasonable approximations of bicarbonate and alkali secretion for each subject on separate occasions. Subjects were more tolerant of the procedure on the second occasion with a tendency towards reduced salivary and gastric contamination within the oesophagus.

\section{ACID PERFUSION STUDIES: EFFECT ON SALIVARY} SECRETION

During the period in which the oesophagus was perfused with $25 \mathrm{ml}$ of $0.1 \mathrm{M} \mathrm{HCl}$ over five 


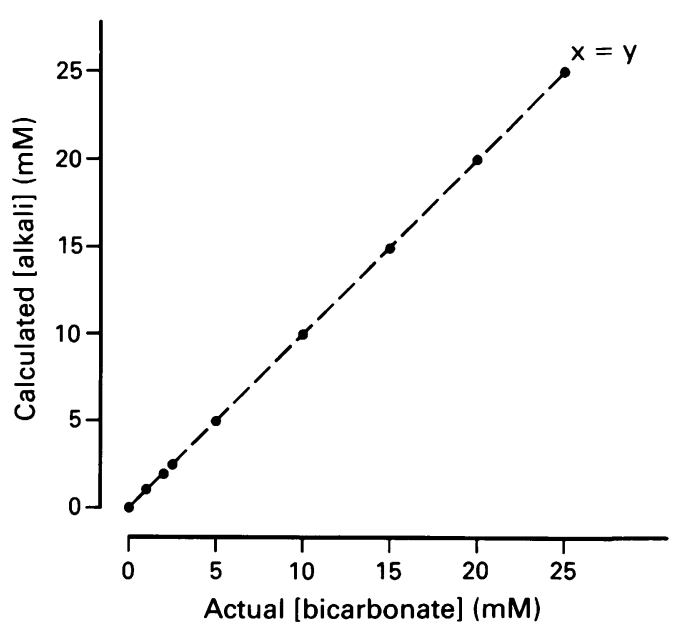

Figure 6: Accuracy of the sensitive back titration technique in determining the alkali content of standard bicarbonate solutions $(n=27, r=1 \cdot 0, p=0.0001$, average $\%$ difference $=$ $0 \cdot 2 \%)$.

minutes in eight subjects, no symptoms were reported and mean salivary bicarbonate secretion was unaltered (basal $5665 \mu \mathrm{mol} /$ hour, after acid bolus $5337 \mu \mathrm{mol} / \mathrm{hour}, \mathrm{p}=0.94$ ).

In 12 subjects the oesophagus was perfused continuously with $0 \cdot 1 \mathrm{M} \mathrm{HCl}$ for 30 minutes. Two subjects did not experience symptoms due to acid perfusion and no increase in salivary bicarbonate output occurred. Ten other subjects experienced nausea and heartburn in association with acid perfusion of the oesophagus and median salivary bicarbonate secretion increased from a basal $401 \mu \mathrm{mol} / 15$ minutes to $497 \mu \mathrm{mol}$ $(\mathrm{p}=0.02)$ and $1100 \mu \mathrm{mol}$ during the two 15 minute periods of acid perfusion (Fig 7). Salivary bicarbonate concentrations did not increase significantly and the increased bicarbonate secretion was largely due to an increase in salivary volume from median $34 \mathrm{ml} / 15$ minutes basal to $46.5 \mathrm{ml} / 15$ minutes $(\mathrm{p}=0.006)$ and $55.0 \mathrm{ml} / 15$ minutes during the two periods of acid perfusion. The difference in baselines between these two groups results from the large degree of individual variation in salivary secretion.

\section{Discussion}

In the oesophagus, mucosal integrity depends on a balance between aggressive factors such as

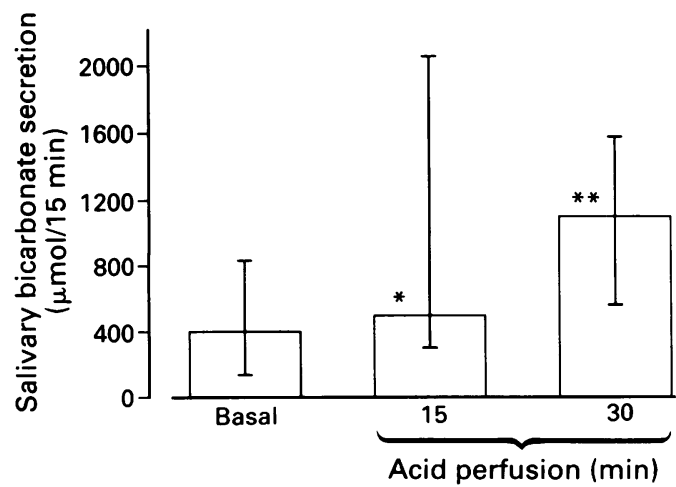

Figure 7: Oesophageal perfusion with $0 \cdot 1 \mathrm{~N} \mathrm{HCl}$ $(5 \mathrm{ml} / \mathrm{minute}$ over 30 minutes) is associated with symptoms in 10 subjects (nausea and heartburn), and enhancement of salivary bicarbonate secretion $\left({ }^{\star} p=0.019 ;{ }^{\star \star} p=0.009\right)$. salivary bicarbonate secretion $\left({ }^{\star} p=0.019 ;{ }^{\star \star} p=0.009\right)$
Median values and $95 \%$ confidence intervals are given. refluxed acid and pepsin, ${ }^{12}$ and protective mechanisms that include salivary and oesophageal bicarbonate secretion, ${ }^{45}$ salivary and oesophageal mucus, ${ }^{13}$ mucosal resistance and permselectivity, ${ }^{14}{ }^{15}$ proliferative activity of the epithelium, ${ }^{16}$ mucosal blood flow, ${ }^{17}$ and motor activity that enhances clearance and maintains competence of the gastro-oesophageal junction. ${ }^{18}$ After an episode of acid reflux, secondary oesophageal peristalsis can reduce the remaining bolus to less than $1 \mathrm{ml}$. Studies have shown that exogenous radiolabelled acid instilled in the oesophagus can be cleared after two swallows. ${ }^{19}$ Despite these clearance mechanisms, a small volume of acid remains, reducing oesophageal intraluminal $\mathrm{pH}$ and creating an environment for mucosal injury.

Swallowed saliva is now regarded as an important mechanism for neutralising acid within the oesophageal lumen and oesophageal pH exhibits an incremental increase with repeated swallows. ${ }^{2021}$ The major source of the neutralising capacity of saliva is its bicarbonate content, ${ }^{22}$ but there is now evidence that gland bearing oesophageal mucosa can also secrete alkali, a phenomenon first documented in the opossum oesophagus in vivo. ${ }^{5}$ This alkali can contribute to acid neutralisation and the intraoesophageal $\mathrm{pH}$ increases with time in response to acid even in the absence of salivary secretion. Similar experiments on rabbit oesophagus, which is devoid of submucosal glands, failed to show alkali secretion suggesting that these glands are the source of oesophageal alkalinisation. These experimental findings may be relevant to humans, as similar submucosal glands have been described in the oesophagus for more than 80 years. Several lobules of small tubuloacinar glands drain into a common duct that leads to the surface of the squamous epithelium, and with histological techniques, use of acid toluidine blue has identified irregular longitudinal rows of ductal ostia in the human oesophagus. ${ }^{23}$

Perfusion techniques have been used to investigate secretion and absorption in the human gut in vivo. The ideal system involves isolating a segment of gut, thus preventing contamination from above or below and allowing $100 \%$ recovery of perfused solution. The technique that most closely approaches these ideals, is that used by Isenberg's group to investigate duodenal bicarbonate secretion. ${ }^{8}$ The oesophagus is a muscular segment, the main function of which is the passage of ingested food and fluid from the pharynx into the stomach. The response to bolus distension within the oesophagus is proximal contraction and distal relaxation and the generation of an aboral contraction wave. Inflation of an intraoesophageal balloon to between 2 and $2.5 \mathrm{~cm}$ diameter $(8$ to $9 \mathrm{ml}$ ), causes pain in normal subjects and is associated with peristaltic activity. ${ }^{24}$ These findings are consistent with our early experience, when attempts were made to isolate a $10 \mathrm{~cm}$ segment of oesophagus between two occluding balloons in six subjects. This system was not tolerated in pilot experiments, and we decided to perfuse an open segment of oesophagus and make appropriate corrections for contaminating 
saliva and refluxed gastric fluid. ${ }^{25}$ Another group has published preliminary findings on alkaline secretion in a balloon occluded segment of human oesophagus. ${ }^{26}$ The potential advantages of balloon occlusion were not realised, however, with appreciable contamination by saliva ( $20 \%)$ and incomplete oesophageal fluid recovery.

In our study an open segment of oesophagus was perfused and recovered fluid analysed for bicarbonate contents, with deductions made for salivary contamination and refluxed gastric fluid. In 32 healthy subjects without symptoms median net oesophageal bicarbonate output was 416 $\mu \mathrm{mol} / \mathrm{hour} / 10 \mathrm{~cm}$ with contaminating saliva and refluxed gastric fluid contributing $25 \%$ and $2 \cdot 5 \%$ of total bicarbonate measured in the oesophageal segment by the $\mathrm{pH} / \mathrm{pCO}_{2}$ method. About $50 \%$ of the infused solution was recovered. There was also an excellent correlation between the quantity of exogenous bicarbonate infused into the oesophagus and that measured and calculated from oesophageal aspirates. Evidence is also presented which suggests that amylase determination in oesophageal fluid is an accurate reflection of salivary contamination. In vitro studies show only a $2 \%$ reduction in amylase activity when salivary $\mathrm{pH}$ is reduced from $8 \cdot 2$ to $7 \cdot 2$.

One potential criticism of the $\mathrm{pH} / \mathrm{pCO}_{2}$ method is that investigators may be measuring dissolved $\mathrm{CO}_{2}$ in perfusing solution that has diffused as $\mathrm{CO}_{2}$ gas down a mucosa to lumen concentration gradient, rather than occurring due to secreted bicarbonate ions. A sensitive back titration technique was therefore used in 15 experiments to determine salivary and oesophageal alkali outputs, and to compare these with bicarbonate outputs as determined by the $\mathrm{pH} / \mathrm{pCO}_{2}$ method. In vitro experiments show back titration to be very accurate and precise in determining the alkali content of standard bicarbonate solutions. Median oesophageal alkali output was $563 \mu \mathrm{mol} / \mathrm{hour} / 10 \mathrm{~cm}$ (back titration) compared with a median bicarbonate output of $489 \mu \mathrm{mol} / \mathrm{hour} / 10 \mathrm{~cm}\left(\mathrm{pH} / \mathrm{pCO}_{2}\right.$ method). The two methods correlated $(r=0 \cdot 69)$ and did not give significantly different overall outputs $(\mathrm{p}=0 \cdot 38)$. With back titration, swallowed saliva accounted for a median $17 \%$ of alkali within the oesophagus whereas refluxed gastric alkali contributed $1 \cdot 0 \%$. The $\mathrm{pH} / \mathrm{pCO}_{2}$ method slightly overestimated oesophageal fluid alkali concentration but the error was much greater for salivary analysis due to its higher $\mathrm{pH}$. Less variable results were obtained with back titration and for these reasons, we suggest that back titration is the analytical technique of choice for determining alkali concentrations in saliva and oesophageal fluid.

Our findings have important implications for oesophageal defence against acid and pepsin injury. The human oesophagus secretes bicarbonate at about $400 \mu \mathrm{mol} / \mathrm{hour} / 10 \mathrm{~cm}$, which is a similar order of magnitude to gastric bicarbonate secretion. The finding that oesophageal acidification increases salivary bicarbonate is of particular interest and is in agreement with previously published results by Helm and coworkers. ${ }^{5}$ These studies imply the existence of an oesophagosalivary reflex that may be responsible for the symptom of 'waterbrash'. Whether this response occurs only in symptomatic subjects remains controversial as one group of investigators have reported acid stimulated salivary bicarbonate secretion in the absence of symptoms. ${ }^{27}$

The data from these studies do not allow us to comment on the mechanism of human oesophageal secretion, but evidence in mammals suggests the importance of submucosal glands. Finally, the physiological relevance of oesophageal bicarbonate secretion remains to be investigated as a mucus-bicarbonate barrier may not exist in the oesophagus, by contrast with the stomach and duodenum. ${ }^{28}$

Dr C M Brown is a Wellcome Trust Clinical Research Fellow. We are grateful to Professor L A Turnberg for critical advice, Mrs Sally Hollis for statistical advice, Dr Kay Fogg and the Department of Medical Illustration at Hope Hospital for preparing the figures, and to Mrs Julie Young for preparing the manuscript.

Some of the results were presented at meetings of the British Society of Gastroenterology at Southampton on 27 Septembe 1990 and at London on 25 September 1991, and also at a meeting of the American Gastroenterological Association at San Francisco on 13 May 1992 . These results were published in absisco on 13 May 1992 . These results were published in abstract form 1992; 102: A45).

1 Dent J. Recent views of the pathogenesis of gastro-oesophageal reflux disease. Clinical Gastroenterology 1987; 1: 727-45.

2 Dent J, Holloway RH, Toouli J, Dodds WJ. Mechanisms of lower oesophageal sphincter incompetance in patients with symptomatic gastro-oesophageal reflux. Gut 1988; 29 $1020-8$.

3 Thompson DG, Andreollo NA, McIntyre AS, Earlam RJ Studies of the oesophageal clearance responses to intraluminal acid. Gut 1988; 29: 881-5.

4 Helm JF, Dodds WJ, Hogan WJ. Salivary response to esophageal acid in normal subjects and patients with reflux esophagitis. Gastroenterology 1987; 92: 1393-7.

5 Hamilton $\mathrm{BH}$, Orlando RC. In vivo alkaline secretion by mammalian esophagus. Gastroenterology 1989; 97: 640-8.

6 Al Yassin TM, Toner PG. Fine structure of squamous epithelium and submucosal glands of human oesophagus. F Anat 1977; 123: 703-21.

7 Rees WDW, Botham D, Turnberg LA. A demonstration of bicarbonate production by the normal human stomach. Dig Dis Sci 1982; 27: 961-6.

8 Isenberg JI, Hogan DL, Koss MA, Selling JA. Human duodenal mucosal bicarbonate secretion. Evidence for basal secretion and stimulation by hydrochloric acid and a synthetic prostaglandin $\mathrm{E}_{1}$ analogue. Gastroenterology 1986 91: 370-8.

9 Rees WDW, Go VLW, Malagelada JR. Simultaneous measurement of antroduodenal motility, gastric emptying

10 Scholer A. Evaluation of a colorimetric test for the determination of $\alpha$-amylase with p-nitrophenylheptaoside as substrate. tion of $\alpha$-amylase with p-nitrophenylheptaos

11 Ying Foo A, Rosalki SB. Measurement of plasma amylase activity. Ann Clin Biochem 1986; 23: 624-37.

12 Gotley DC, Morgan AP, Ball D, Owen RW, Cooper MJ Composition of gastro-oesophageal refluxate. Gut 1991; 32 1093-9.

13 Sarosiek J, Feng T, McCallum RW. The interrelationship between salivary epidermal growth factor and the functional integrity of the esophageal mucosal barrier in the rat. $A m \mathcal{F}$ Med Sci 1991; 302: 359-63.

14 Powell DW. Barrier function of epithelia. Am f Physiol 1981; 241: G275-88.

15 Orlando RC, Bryson JC, Powell DW. Mechanisms of $\mathrm{H}^{+}$ injury in rabbit esophageal epithelium. Am $\mathcal{F}$ Physiol 1984 246: G718-24.

16 Johnson LE. Regulation of gastrointestinal growth. In Johnson LR, ed. Physiology of the gastrointestinal tract. New York: Raven Press, 1987, 301.

17 Duda G, Huesken JE, Harmon JW. Effects of prostaglandin on esophageal blood flow. F Surg Res 1988; 44: 371-81.

18 Kahrilas PJ, Dodds WJ, Kern HM, Arndorfer RC, Reece A Esophageal peristaltic dysfunction in peptic esophagitis Gastroenterology 1986; 91: 897-904.

19 Helm JF, Dodds WJ, Pelc LR, Palmer DW, Hogan WJ, Teeter BC. Effect of esophageal emptying and saliva on clearance of acid from the esophagus. N Engl F Med 1984; 310: $284-8$.

20 Helm JF, Dodds WJ, Riedel DR, Teeter BC, Hogan WJ, Arndorfer RC. Determinants of esophageal acid clearance in Arndorfer RC. Determinants of esophageal acid clear

21 Shaker R, Kahrilas PJ, Dodds WJ, Hogan WJ. Oesophageal clearance of small amounts of equal or less than one millilitre clearance of small amounts

22 Helm JR, Dodds WJ, Hogan WJ, Soergel KH, Egide MS, 
Wood CM. Acid neutralizing capacity of human saliva. Gastroenterology 1982; 83: 69-74.

23 Hopwood D, Coghill G, Sanders DSA. Human oesophageal submucosal glands. Their detection mucin, enzyme and secretory protein content. Histochemistry 1986; 86: 107-12. De Caestecker JS, Pryde A, Heading RC. Site and mechanism of pain perception with oesophageal balloon distension and intravenous edrophonium in patients with oesophageal ches pain. Gut 1992; 33: 380-6.

25 Brown CM, Botham D, Rees WDW. Human oesophageal bicarbonate secretion - $\mathrm{a}$ factor in oesophageal acid clearance? Gut 1990; 31: A1192.

26 Meyers RL, Orlando RC. Bicarbonate $\left(\mathrm{HCO}_{3}{ }^{-}\right)$secretion by human oesophagus. Gastroenterology 1992; 102: A126.

27 Sonnenberg A, Steinkamp U, Weise A, Berges W, Weinbeck $M$, Rohner HG, Peter P. Salivary secretion in reflux esophagitis. Gastroenterology 1982; 83: 889-95.

28 Quigley EMM, Turnberg LA. pH of the microclimate lining human gastric and duodenal mucosa in vivo. Gastroenterology 1987; 92: 1876-84. 